ACTA

STOMATOLOGICA

CROATICA

www.ascro.hr
Acta stomatol Croat. 2021;55(3):291-301.

DOI: $10.15644 / \operatorname{asc} 55 / 3 / 6$

ORIGINAL SCIENTIFIC PAPER

IZVORNI ZNANSTVENI RAD

(c) (i) (9)

Ankita Dilip Amonkar ${ }^{1}$, Neha Sunil Dhaded ${ }^{2}$, Preeti Kore Doddwad², Anand C. Patil², Shivayogi M. Hugar ${ }^{3}$, Shilpa Bhandi ${ }^{4}$, A. Thirumal Raj ${ }^{5}$, Shankargouda Patil ${ }^{6}$, Alessio Zanza ${ }^{7}$, Luca Testarelli ${ }^{7}$

\title{
Evaluation of the Effect of Long-term Use of Three Intracanal Medicaments on the Radicular Dentin Microhardness and Fracture Resistance: An in vitro study
}

\section{Usporedba dugotrajne primjene triju intrakanalnih lijekova na mikrotvrdoću i otpornost na lom korijenskog dentina: in vitro istraživanje}

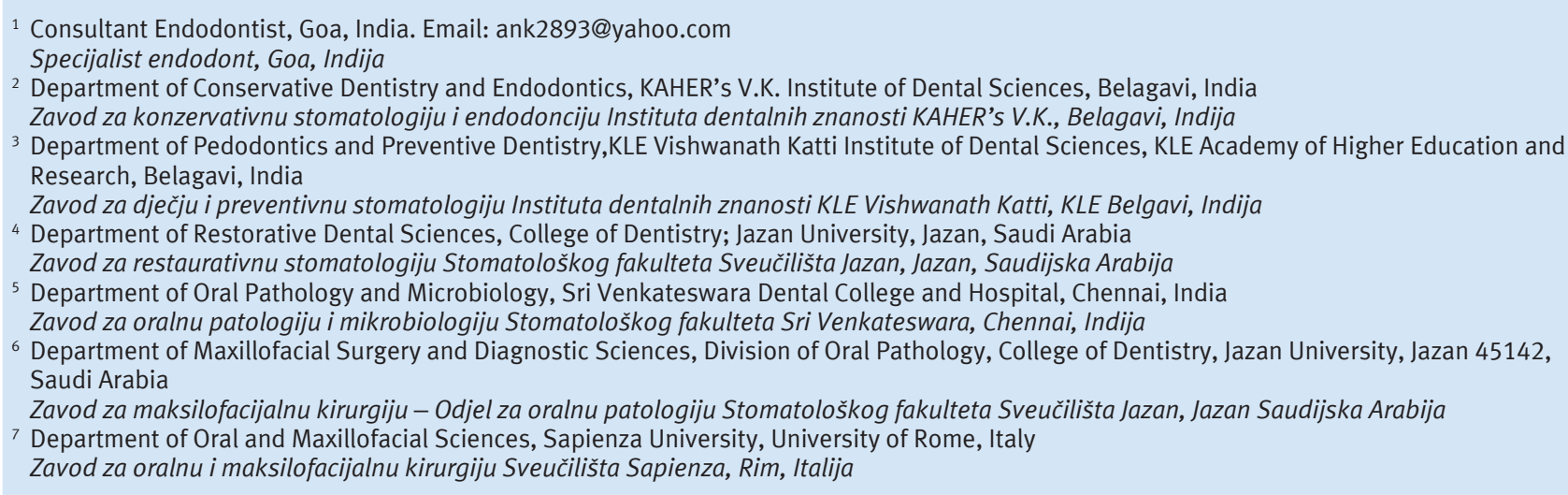

\section{Abstract}

Objectives: The aim of this research was to evaluate the effect of long-term use of three intracanal medicaments on the radicular dentin microhardness and fracture resistance. Material and methods: A chemomechanical preparation was done using the Protaper rotary instruments up to F3. The teeth were stored in an incubator at $37^{\circ} \mathrm{C}$ at $100 \%$ humidity and were categorized in three groups by random allocation, namely: Triple Antibiotic Paste (TAP), Calcium hydroxide paste (Apexcal) and Ledermix. Following medicament application, the access openings of all teeth were sealed with $4 \mathrm{~mm}$ thickness of cavit. The samples were stored for periods of 1 week, 1 month and 3months. Two dentin cylinders measuring $5 \mathrm{~mm}$ and $3 \mathrm{~mm}$ were obtained from each sample. The cervical third was used for fracture resistance and the middle third was used for micro hardness evaluation. The microhardness testing was done using a Knoop microhardness tester, and the fracture resistance testing was done using the universal testing machine. Results: Calcium hydroxide showed maximally negative effect on the physical properties of radicular dentin compared to TAP $(p=0.0100$ at one month and Ledermix ( $p=0.0001$ at one month ). With an increase in the application time, there was an increased deterioration in the physical properties of radicular dentin. Conclusion: Long-term placement of calcium hydroxide, Triple Antibiotic Paste, and Ledermix ( $p=0.0001$ at 3 months) significantly affects the microhardness and fracture resistance of radicular dentin.
Received: May 8, 2021

Accepted: August 1, 2021

Address for correspondence Alessio Zanza University of Rome Sapienza University Department of Oral and Maxillofacial Sciences

Rome 00185, Italy

ale.zanza@gmail.com

MeSH terms: Root Canal Filling Materials; Dentine; Hardness Tests; Flexural Strength

Author keywords: Ledermix; Triple Antibiotic Paste; Microhardness; Fracture Resistance; Calcium Hydroxide

\section{Introduction}

The root canal system is comprised of the main canal and various complexities such as lateral canals, ramifications, loops, isthmuses, deltas (1). In infected root canals, bacteria, which persist deep within the dentin, may be difficult to eradicate and trigger periapical pathosis (2). During a root
Uvod

Sustav korijenskog kanala sastoji se od glavnog kanala i različitih lateralnih kanala, ramifikacija, petlji, istmusa i delti (1). Zato je u slučaju infekcije teško eliminirati bakterije duboko unutar dentina koje izazivaju periapikalnu patologiju (2). Istaknimo da tijekom instrumentacije korijenskog kana- 
canal preparation almost half of the root canal surface and ramifications may remain untouched (3).

An adequate chemo-mechanical preparation to obtain a three-dimensional seal is important to attain a successful endodontic therapy (4). Failure of endodontic treatment is most commonly related to the perseverance of pathogenic microbes that thrive very well even after a thorough cleaning and shaping is done (5).

Combined use of adequate isolation techniques, biomechanical preparation, effective irrigating solutions and techniques, along with a proven disinfecting medicament play a major role in determining the success of a root canal therapy (6).

Medicaments play a major role in preparing the root canals for long term treatment protocols, especially in situations of regenerative endodontics and apexification. Calcium hydroxide (CH), Triple Antibiotic Paste (TAP), Double Antibiotic Paste (DAP) and Ledermix are the most commonly used intracanal medicaments (7).

Calcium hydroxide $(\mathrm{CH})$ is widely used to achieve disinfection within the root canal. It is also used for the induction of apexogenesis and apexification, in management of internal eradicular resorptive defects, various perforations and in treating periradicular pathoses; nevertheless, it has been used as a dental-pulp capping agent $(8,9)$.

Bystrom et al. confirmed the fact that $E$. faecalis is the most resilient strain against $\mathrm{CH}(10-11)$.

Various studies have proved that long-standing use of $\mathrm{CH}$ may have an adversative effect on the physical properties of radicular dentin (12). Almost 50\% of reduction in microtensile fracture strength (MTFS) of teeth was seen by Rosenberg et al. while they were studying long-term application of $\mathrm{CH}$ (7-84 days) (13). Even the mean elastic modulus of bovine dentine increased drastically, as seen by Kawamoto et al. (2008), thus making it more prone to fracture (14).

Lately, a newer formulation called 'triple antibiotic paste' (TAP) has been given by Hoshino et al. Ciprofloxacin, metronidazole and minocycline together form TAP (15). The abovementioned antibiotics exhibit effective antimicrobial and antibacterial properties (16).

Trauma and periapical pathosis in immature permanent teeth impede the deposition of minerals by the disruption in blood flow thereby causing cessation of complete root development (17). The apexification technique promotes apical closure by either placement of a MTA apical plug or with periodic changes of intracanal medicaments $(18,19)$. Another treatment option is the Regenerative endodontic procedure which is designed to replace the damaged structures to reestablish the pulp-dentin complex thereby maintaining the vitality of pulp (20). According to Fouad, a complete disinfection is required for a higher level of efficacy than is needed in clinical endodontics (21). Thus, the establishment of a sustained sterile microenvironment within the root canal which is achieved through adequate decontamination procedures will give the newly formed tissue adequate time to establish itself within the endodontic environment (22).

Disinfection of the root canal is considered to be a crucial step as infection prevents regeneration, repair and stem cell la gotovo polovina površine samog kanala i njegovih ogranaka ostane neobrađena (3).

Adekvatna kemijsko-mehanička preparacija kojom se postiže trodimenzionalno brtvljenje važna je za uspješnu endodontsku terapiju (4). Neuspjeh se najčešće veže za trajnu prisutnost patogenih mikroorganizama koji nastavljaju živjeti u dentinu čak i nakon detaljnog čišćenja i širenja kanala (5).

Kombinirana upotreba pravilne izolacijske tehnike (suhoga radnog polja), biomehanička preparacija, učinkovite otopine za ispiranje i tehnika rada te dokazano djelotvorno dezinficirajuće sredstvo ključni su za uspješno liječenje korijenskog kanala (6).

Lijekovi su u protokolima dugotrajne terapije veoma važni u pripremi korijenskog kanala, posebno u slučaju regenerativne endodoncije i apeksifikacije. Kalcijev hidroksid, trostruka antibiotička pasta (TAP), dvostruka antibiotička pasta (DAP) te Ledermix najčešce se primjenjuju kao intrakanalni lijekovi (7).

Kalcijev hidroksid $(\mathrm{CH})$ često je u upotrebi kao sredstvo za dezinfekciju unutrašnjosti korijenskog kanala, a koristi se i za poticanje apeksogeneze i apeksifikacije, u liječenju internih radikularnih resorptivnih defekata, različitih perforacija te u liječenju periapikalne patologije. Upotrebljava se i kao sredstvo za prekrivanje pulpe $(8,9)$.

Bystrom i suradnici potvrdili su da $\mathrm{CH}$ slabo djeluje na bakterije Enterococcus faecalis $(10,11)$.

U mnogim istraživanjima autori su potvrdili da dugotrajna upotreba $\mathrm{CH}$-a nepovoljno utječe na fizička svojstva radikularnog dentina (12). Rosenberg i suradnici opazili su gotovo 50-postotnu redukciju mikrotenzilne snage (MTFS) zuba nakon dugotrajne (7 - 84 dana) upotrebe $\mathrm{CH}-\mathrm{a}$ (13). Čak je i srednji modul elastičnosti goveđeg dentina značajno porastao, čime je postao sklon frakturama (14).

Nedavno su Hoshino i suradnici predstavili noviju formulaciju nazvanu trostruka antibiotička pasta (TAP) koja sadržava ciprofloksacin, metronidazol i minociklin (15). Svi navedeni sastojci imaju antimikrobna i antibakterijska svojstva (16).

Trauma i periapikalna patologija nezrelih trajnih zuba ometaju odlaganje minerala prekidanjem dotoka krvi, te tako zaustavljaju razvoj korijena zuba (17). Apeksifikaciiska tehnika potiče zatvaranje apeksa postavljanjem MTA čepa, ili periodičnim izmjenama intrakanalnih lijekova $(18,19)$. Druga terapijska mogućnost jest regeneracijski endodontski postupak kojim se pokušava zamijeniti oštećene strukture kako bi se ponovno uspostavio pulpno-dentinski kompleks te očuvao vitalitet pulpe (20). Prema stajalištu Fouada, potrebna je potpuna dezinfekcija, u većoj mjeri nego u slučaju kliničke endodoncije (21), pa je uspostava održivoga sterilnoga mikrookoliša unutar korijenskog kanala adekvatnim dekontaminacijskim postupcima prijeko potrebna da bi novostvoreno tkivo dobilo dovoljno vremena za svoju organizaciju unutar endodontskog prostora (22).

Dezinfekcija korijenskog kanala smatra se ključnom zato što infekcija onemogućuje regeneraciju, oporavak i aktivnost matičnih stanica $(23,24)$. Protokol Američkoga društva za endodonciju (AAE) preporučuje upotrebu TAP-a u regeneracijskim endodontskim postupcima (25), ali i u liječenju ra- 
activity $(23,24)$. The American Association of Endodontics (AAE) protocol advocates the use of TAP in regenerative endodontic procedures (25). Its use is also advocated in the treatment of radicular resorptive defects, root fracture, and also in the non-surgical management of periapical pathosis (26).

The use of TAP is associated with a few limitations; Tooth discoloration is the biggest drawback of this medicament, which arises due to the presence of minocycline which has a negative impact on the esthetics of the patient, especially when used in the anterior teeth $(27,28)$. TAP, when used for long term, has shown to cause an increased radicular dentin demineralization and an associated reduction in microhardness $(22,29)$.

Ledermix $^{\text {TM }}$ paste is a commercially available intracanal medicament paste that was introduced by Schroeder and Triadan in 1960. It is a polyethylene glycol-based paste containing tetracycline antibiotic, demeclocycline $\mathrm{HCl}$ (conc. of $3.2 \%$ ), and a corticosteroid, triamcinolone acetonide, conc. $1 \%(30,31)$. It is efficient in alleviating pain, in the inhibition of inflammatory root resorption and as an antimicrobial agent (32). In cases of root resorption and large periapical lesions, Ledermix is kept for a prolonged period of time $(33,34)$. Long term exposure of enamel to Ledermix causes a drastic reduction in the microhardness which is due to the aqueous tetracycline component. Due to lack of literature in this field this study was designed to evaluate the longterm impact of these medicaments on properties such as microhardness and fracture resistance of radicular dentin.

The aim of this work is to compare and evaluate the effect of long-term use of three intracanal medicaments on the radicular dentin microhardness and fracture resistance.

\section{Null hypothesis}

There is no difference in the effect of long term placement of calcium hydroxide, Triple Antibiotic Paste and Ledermix on the radicular dentin micro hardness and fracture resistance.

\section{Material and methods}

\section{Source of data}

The study was conducted in Department of Conservative Dentistry and Endodontics, KAHER' s KLE VK Institute of Dental Sciences', KLE Academy of Higher Education and Research (KLE University) Belagavi.

The microhardness testing was conducted at M.I.T (Manipal Institute of Technology). The fracture resistance testing was performed at K.L.E Engineering College Belagavi. A total of 180 extracted, human permanent single rooted premolar teeth were selected.

\section{Selection criteria}

Extracted human permanent single rooted premolar teeth with patent canals and the teeth with apical width corresponding to \#20 K-file or less were included. Carious teeth, teeth with apical width more than \#20 K-file size, teeth with calcified canals, teeth with fracture/crack or a restoration, teeth with internal/external resorption were excluded. dikularnih resorptivnih defekata, fraktura korijena te u nekirurškom zbrinjavanju periapikalne patologije (26).

Upotreba TAP-a povezana je s nekoliko ograničenja, a najveće je diskoloracija zuba zbog minociklina, što može negativno utjecati na estetiku, posebno ako se koristi na prednjim zubima $(27,28)$. Pokazalo se da TAP potiče povećanu demineralizaciju radikularnog dentina i smanjuje njegovu mikrotvrdoću $(22,29)$.

Pasta Ledermix ${ }^{\text {TM }}$ komercijalno je dostupna intrakanalna medikamentna pasta koju su predstavili Schroeder i Triadan 1960. godine kao proizvod na bazi polietilen glikola koji sadržava tetraciklinski antibiotik, demeklociklin $\mathrm{HCl}(3,2$ $\%)$ te kortikosteroid triamcinolon acetonid $(1 \%)(30,31)$. Učinkovit je u uklanjanju boli, inhibiciji upalne resorpcije korijena te kao antimikrobno sredstvo (32). U slučaju resorpcije korijena i velikih periapikalnih lezija Ledermix se ostavlja dulje u korijenskom kanalu $(33,34)$. No dulja izloženost cakline Ledermixu može drastično smanjiti mikrotvrdoću zbog vodene komponente tetraciklina. Kako nema dovoljno literature o toj temi, u ovom istraživanju htio se procijeniti dugotrajni utjecaj tih lijekova na mikrotvrdoću i otpornost na lom radikularnog dentina.

Svrha ovog istraživanja bila je usporediti i procijeniti učinak dugotrajne upotrebe triju intrakanalnih lijekova na mikrotvrdoću i otpornost na lom radikularnog dentina.

\section{Nulta hipoteza}

Poslije dugotrajne upotrebe nema razlike u učinku kalcijeva hidroksida, trostruke antibiotičke paste i Ledermixa kad je riječ o mikrotvrdoći i otpornosti na lom radikularnog dentina.

\section{Materijal i metode}

\section{Izvor podataka}

Istraživanje je provedeno u Zavodu za restaurativnu dentalnu medicinu i endodonciju KAHER's KLE VK Instituta dentalnih znanosti KLE u Belagaviju.

Testiranje mikrotvrdoće obavljeno je u Tehnološkom institutu u Manipalu, a otpornost na lom na Inženjerskom fakultetu KLE u Belagaviju. Odabrano je 180 ekstrahiranih jednokorijenskih ljudskih pretkutnjaka.

\section{Kriteriji za odabir}

$\mathrm{U}$ istraživanje su bili uključeni ekstrahirani jednokorijenski ljudski pretkutnjaci s prohodnim kanalima i to oni koji su na apeksu imali prohodnost pri uporabi pilice br. 20 ili manje. Zubi s karijesom, širim apeksom, kalcificiranim kanali$\mathrm{ma}$, frakturama/pukotinama ili ispunima te zubi s internom/ eksternom resorpcijom nisu bili uključeni u istraživanje. 


\section{Methodology}

180 extracted, human single rooted premolar teeth were selected. Cleaning of visible blood and gross debris was done using an ultrasonic scaler. The extracted teeth were handled according to OSHA (Occupational Safety and Health Administration) guidelines. $0.1 \%$ thymol solution was used for the storage of the samples until use.

A round bur with a high-speed handpiece was used to make an access cavity in each tooth specimen. Apical patency was attained using a size $10 \mathrm{~K}$ file ((Mani. Inc., Tochigi, Japan. A 15 K-file (Mani. Inc., Tochigi, Japan) was extended $1 \mathrm{~mm}$ beyond the apical foramen by visualizing its tip, following which $1 \mathrm{~mm}$ was removed from the predetermined working length. Shaping and cleaning was carried out using the Protaper (Dentsply, India) rotary instruments till F3 with endo motar(X -Smart, Dentsply, India). In between each instrumentation change, the canals were irrigated with $2 \mathrm{~mL}$ of $3 \% \mathrm{NaOCl}$ (Vishal Dentocare Pvt. Ltd., Ahmedabad India), followed by $2 \mathrm{~mL}$ of $17 \%$ EDTA (DEOR Deo Smear-Off, India) as the final irrigant. The canals were subsequently rinsed with 5 -mL of sterile saline using a 27 -gauge needle. Following irrigation of teeth, sterile paper points (Dentsply, India) were used to dry the root canals.

The teeth were stored in an incubator at $37^{\circ} \mathrm{C}$ at $100 \%$ humidity. The teeth were stored for periods of 1 week, 1 month and 3months.

\section{Medicament application}

180 specimens were allocated to the following three groups: Group I: Triple Antibiotic Paste (TAP); Group II: Calcium hydroxide paste (Apexcal); Group III: Ledermix

\section{Group I: Triple Antibiotic Paste (TAP)}

1 st experimental group $(n=60)$, For the preparation of TAP, $1 \mathrm{mg} / \mathrm{ml}$ of each antibiotic powders (USP-grade) in equal quantities of metronidazole, ciprofloxacin and minocycline in a ratio of 3:1 was combined with polyethylene glycol. A sterile lentulo spiral was used for the introduction of the prepared medicament into the root canals with a slow-speed handpiece. Following this, the medicament was compacted to the level of the CEJ using sterile pluggers (Sybron endo).

\section{Group II: Calcium hydroxide paste (Apexcal)}

For the second experimental group $(n=60)$, commercially available $\mathrm{Ca}(\mathrm{OH}) 2$ paste (Apexcal) was used. The medicament application to the root canal space was done in a similar manner as described previously.

\section{Group III: Ledermix}

For the third experimental group $(n=60)$, commercially available Ledermix paste was used. The paste was introduced into the root canals as elaborated previously. Following medicament application, $4 \mathrm{~mm}$ of cavit (3M ESPE) was used to seal all the prepared specimens. After the coronal seal was achieved, flowable composite (Ivoclar Vivadent) was used to obtain an apical seal.

\section{Preparation of root specimens}

A low-speed diamond saw (Agar Scientific) under constant water cooling was used for decoronation of the prepared sam-

\section{Metodologija}

Odabrano je 180 ekstrahiranih humanih jednokorijenskih premolara. Vidljive i velike naslage očišćene su ultrazvučnim strugačem. Sa zubima se zatim postupalo prema smjernicama OSHA-e (Occupational Safety and Health Administration). Do početka istraživanja čuvani su u 0,1-postotnoj otopini timola.

Pristupni kavitet učinjen je na svakom zubu okruglim svrdlom s pomoću nasadnog instrumenta $s$ velikim brojem okretaja. Prohodnost do apeksa ustanovljena je pilicom br. 10 (Mani Inc., Tochigi, Japan). Pilicom br. 15 prošlo se $1 \mathrm{~mm}$ preko apikalnog foramena sve do pojave vrha, a taj je milimetar odbijen od unaprijed određene radne duljine. Oblikovanje i čišćenje obavljeno je Protaperovim (Dentsply, Indija) rotirajućim instrumentima do F3 s endomotorom (X-Smart, Dentsply, Indija). Između svake upotrebe dviju pila kanali su isprani s $2 \mathrm{~mL} 3$-postotne otopine $\mathrm{NaOCl}$-a (Vishal Dentocare Pvt. Ltd., Ahmedabad, Indija) i $2 \mathrm{~mL}$ 1-postotne otopine EDTA-e (DEOR Deo Smear-Off, Indija) kao posljednjom otopinom. Kanali su na kraju isprani s $5 \mathrm{~mL}$ sterilne fiziološke otopine s pomoću igle 27. Nakon irigacije kanali su potpuno osušeni sterilnim papirnatim štapićima.

Zubi su odloženi u inkubator na $37^{\circ} \mathrm{C}$ uz 100 -postotnu vlagu i to od tjedan do mjesec dana i tri mjeseca.

\section{Primjena lijekova}

Uzorci su podijeljeni u tri skupine: 1 - trostruka antibiotička pasta (TAP); 2 - pasta od kalcijeva hidroksida (Apexcal); 3 - Ledermix

\section{Skupina 1 - trostruka antibiotička pasta (TAP)}

U prvoj eksperimentalnoj skupini $(\mathrm{n}=60)$ pomiješan je $1 \mathrm{mg}$ svakoga antibiotičkog praška u jednakim količinama (metronidazol, ciprofloksacin i minociklin) s polietilen glikolom u omjeru $3: 1$. Za unos pripremljenog medikamenta u korijenske kanale korišteno je sterilno lentulo svrdlo s malim brojem okretaja. Nakon toga uložak je sterilnim pluggerima (Sybron endo) komprimiran do caklinsko-cementnog spojišta.

\section{Skupina 2 - kalcijev hidroksid (Apexcal)}

$\mathrm{Za}$ drugu eksperimentalnu skupinu $(\mathrm{n}=60)$ odabrana je komercijalno dostupna pasta $\mathrm{Ca}(\mathrm{OH})_{2}$ (Apexcal). Postavljanje lijeka u korijenski kanal obavljeno je na sličan način kao što je već opisano.

\section{Skupina 3-Ledermix}

$\mathrm{Za}$ treću eksperimentalnu skupinu $(\mathrm{n}=60)$ korištena je komercijalno dostupna pasta Ledermix. Unesena je u korijenske kanale kako je već opisano. Nakon toga svaki je uzorak zatvoren s $4 \mathrm{~mm}$ Cavita (3M ESPE). Nakon koronalnog brtvljenja, apikalno brtvljenje postignuto je tekućim kompozitom (Ivoclar Vivadent).

\section{Priprema uzoraka korjenova}

Krune su uklonjene dijamantnom pilom s malim brojem okretaja (Agar Scientific) pod konstantnim ispiranjem, 0,5 
ples, $0.5 \mathrm{~mm}$ radicular to the CEJ. The decoronated segment was then sectioned horizontally in order to obtain 2 radicular dentin discs. Fracture resistance assessment was performed on the 5-mm section cervical to the CEJ and microhardness evaluation was made on the middle third 3-mm root section. 5 $\mathrm{mL}$ of sodium hypochlorite in combination with gentle, manual agitation with a ProTaper F3 instrument followed by final irrigation with $5 \mathrm{~mL}$ of EDTA was used for the elimination of the medicament from each prepared section.

\section{Microhardness testing}

A Vickers Microhardness Tester (MCS Mechatronic) was used to measure the microhardness of each tooth specimen. Three indentations were created on the polished surface of each specimen with the help of a 50-g load held straight to the polished side for $15 \mathrm{~s}$. The indentations were made 500 $\mathrm{lm}$ from the pulp dentin interface. The optical microscope was used to observe indentations created. The mean of the values obtained for the three indentations was representative for each specimen at each depth.

\section{Fracture resistance testing}

The Universal testing machine (MCS Mechatronic) was used for assessment on each $5-\mathrm{mm}$ root section. The lower platform was used to place the specimen vertically with the coronal side facing upwards. A cylindrical loading fixture with a radius $=1.9 \mathrm{~mm}$ was fixed to the upper crosshead until the spherical tip touched the root specimen. A loading force at a cross head speed of $0.5 \mathrm{~mm}$ per minute was applied until the root cylinder fractured and was expressed in newtons.

\section{Results}

Comparisons of three groups with micro-hardness and fracture resistance at different time points are respectively shown in Figure 1 and Figure 2. Data analysis with Tukey's multiple posthoc for hardness and fracture resistance is shown in Table 1 and Table 2. mm apikalno od caklinsko-cementnog spojišta. Segment bez krune horizontalno je prerezan da bi se dobila dva radikularna dentinska diska. Procjena otpornosti na lom provedena je na petmilimetarskim presjecima cervikalno od caklinsko-cementnog spojišta, a procjena mikrotvrdoće na trimilimetarskim presjecima sredine korijena. Za ispiranje lijekova korišteno je $5 \mathrm{~mL}$ natrijeva hipoklorita u kombinaciji s nježnim, manualnim pomicanjem instrumenta ProTaper F3, a na kraju je sve isprano s $5 \mathrm{~mL}$ EDTA-e.

\section{Ispitivanje mikrotvrdoće}

Za mjerenje mikrotvrdoće svakog uzorka korišten je uređaj Vickers Microhardness (MCS Mechatronics). Učinjene su tri indentacije na poliranoj površini svakog uzorka s pomoću utega težine 50 grama pritisnutog 15 sekunda na poliranu površinu. Indentacije su napravljene $500 \mathrm{~lm}$ od spoja pulpe i dentina. Pregledane su optičkim mikroskopom, a srednja vrijednost svih triju korištena je kao reprezentativna mjera za svaki uzorak na svakoj dubini.

\section{Ispitivanje otpornosti na lom}

$\mathrm{Za}$ procjenu otpornosti na svakom presjeku korišten je uređaj Universal Testing Machine (MCS Mechatronics). Na donju platformu uzorak je postavljen okomito, s koronalnim dijelom prema gore. Cilindrični vijak promjera $1,9 \mathrm{~mm}$ postavljen je na gornju križnu glavu tako da njegov vrh dodiruje uzorak korijena. Primijenjena sila od $0,5 \mathrm{~mm}$ u minuti sve dok korijen nije puknuo izražena je u njutnima $(\mathrm{N})$.

\section{Rezultati}

Usporedba triju skupina s mikrotvrdoćom i otpornost na lom u različitim vremenskim odsječcima prikazani su na slikama 1 i 2 . Analiza podataka Tukeyjevom multiplom posthoc analizom za mikrotvrdoću i otpornost na lom nalazi se u tablicama 1 i 2.

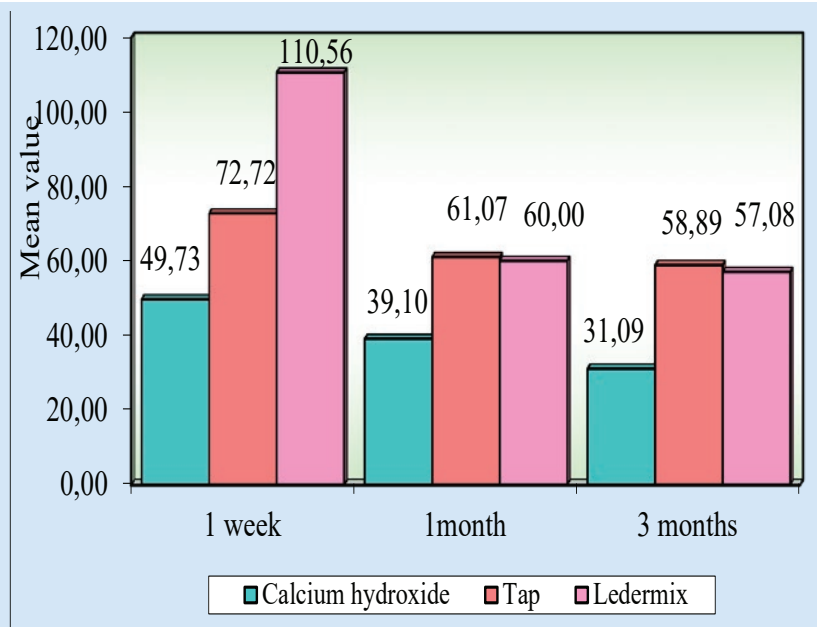

Figure 1 Comparison of three groups with micro hardness at different time points

Slika 1. Usporedba tri skupine s mikrotvrdoćom u različitim vremenskim točkama

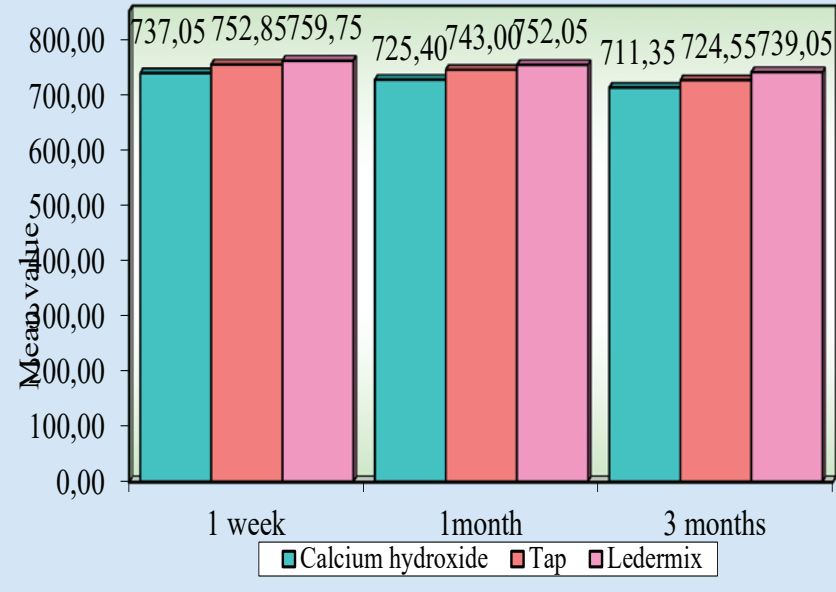

Figure 2 Comparison of three groups with fracture resistance at different time points

Slika 2. Usporedba tri skupine s otporom na lom u različitim vremenskim točkama 
Table 1 Pair wise comparison of three groups with micro hardness at different time points by Tukey's multiple posthoc procedures Tablica 1. Usporedba tri skupine s mikrotvrdoćom u različitim vremenskim točkama Tukeyjevim višestrukim postupcima

\begin{tabular}{|c|c|c|c|c|c|}
\hline Times & Groups vs & Groups & $\begin{array}{c}\text { Mean } \\
\text { Difference }\end{array}$ & Std. Error & p-value \\
\hline \multirow{3}{*}{1 week } & Calcium hydroxide vs $\bullet$ & Tap & -22.99 & 5.44 & $0.0001^{* *}$ \\
\hline & Calcium hydroxide vs & Ledermix & -60.83 & 5.44 & $0.0001^{* *}$ \\
\hline & Tap vs & Ledermix & -37.84 & 5.44 & $0.0001^{* *}$ \\
\hline \multirow[b]{2}{*}{1 month } & Calcium hydroxide vs & Tap & -21.97 & 2.31 & $0.0001^{* *}$ \\
\hline & Calcium hydroxide vs & Ledermix & -20.90 & 2.31 & $0.0001^{* *}$ \\
\hline \multirow{3}{*}{3 months } & Calcium hydroxide vs & Tap & -27.80 & 2.32 & $0.0001^{* *}$ \\
\hline & Calcium hydroxide vs & Ledermix & -25.99 & 2.32 & $0.0001^{* *}$ \\
\hline & Tap vs & Ledermix & 1.81 & 2.32 & 0.7180 \\
\hline
\end{tabular}

Table 2 Pair wise comparison of three groups with fracture resistance at different time points by Tukey's multiple posthoc procedures Tablica 2. Usporedba tri skupine s otpornošću na prijelom u različitim vremenskim točkama Tukeyjevim višestrukim postupcima

\begin{tabular}{|c|c|c|c|c|c|}
\hline Times & Groups vs & Groups & $\begin{array}{c}\text { Mean } \\
\text { Difference }\end{array}$ & Std. Error & p-value \\
\hline \multirow{3}{*}{1 week } & Calcium hydroxide vs & Tap & -15.80 & 5.78 & $0.0220^{*}$ \\
\hline & Calcium hydroxide vs & Ledermix & -22.70 & 5.78 & $0.0010^{* *}$ \\
\hline & Tap vs & Ledermix & -6.90 & 5.78 & 0.4610 \\
\hline \multirow[b]{2}{*}{1 month } & Calcium hydroxide vs & Tap & -17.60 & 5.81 & $0.0100^{*}$ \\
\hline & Calcium hydroxide vs & Ledermix & -26.65 & 5.81 & $0.0001^{* *}$ \\
\hline \multirow{3}{*}{3 months } & Calcium hydroxide vs & Tap & -13.20 & 5.85 & 0.0700 \\
\hline & Calcium hydroxide vs & Ledermix & -27.70 & 5.85 & $0.0001^{* *}$ \\
\hline & Tap vs & Ledermix & -14.50 & 5.85 & $0.0420^{*}$ \\
\hline
\end{tabular}

\section{Statistical analysis}

The ANOVA test revealed a significant difference in three groups with microhardness and fracture resistance at different time points by one-way ANOVA between all the three groups i.e., Group I (Calcium hydroxide), Group II (Triple Antibiotic Paste) and Group III (Ledermix). The lowest scores for microhardness were shown by Group I (Calcium hydroxide) $(49.73 \pm 5.25 \%),(39.10 \pm 3.37 \%),(31.09 \pm 1.18$ $\%)$ at 1 week, 1 month and 3 months, respectively. The lowest scores for fracture resistance were shown by Group I (Calcium hydroxide) $(737.05 \pm 14.92 \%),(725.40 \pm 15.74 \%)$, $(711.35 \pm 15.84 \%)$ at 1 week, 1 month and 3 months, respectively. This was significantly different from the other two groups. Group II (Triple Antibiotic Paste) showed the scores for microhardness of $(72.72 \pm 7.93 \%),(61.07 \pm 5.42 \%)$, $(58.89 \pm 6.85 \%)$, and the fracture resistance scores were $(752.85 \pm 16.76 \%),(743.00 \pm 16.54 \%),(724.55 \pm 16.28 \%)$ at 1 week, 1 month and 3 months respectively. Group III (Ledermix) had scores for microhardness of $(110.56 \pm 28.25 \%)$, $(60.00 \pm 10.95 \%),(57.08 \pm 10.64 \%)$, and the fracture resistance scores were $(759.75 \pm 22.30 \%),(752.05 \pm 22.18 \%)$, $(739.05 \pm 22.59 \%)$ at 1 week, 1 month and 3 months respectively. The same values are shown in Figures 1 and 2 .

The pairwise comparison of the three experimental groups is described in detail in Table 1 and 2, and a significant difference was found between the Calcium hydroxide (Group I),Triple Antibiotic Paste (Group II), Ledermix (Group III)on the radicular dentin microhardness and fracture resistance.

\section{Statistička analiza}

ANOVA je pokazala značajnu razliku između triju skupina kad je riječ o odnosima mikrotvrdoće i otpornosti na lom u različitim vremenskim odsječcima. Najniže vrijednosti za mikrotvrdoću zabilježene su u skupini 1 (kalcijev hidroksid) (tjedan dana - 49,73 $\pm 5,25 \%$ ), (mjesec dana - 39,10 $\pm 3,7 \%)$, (3 mjeseca $-31,09 \pm 1,18 \%)$. Najniže vrijednosti otpornosti na lom dobivene su u također skupni 1 (kalcijev hidroksid) tjedan dana $-73705 \pm 14,92 \%$, mjesec dana $725,40 \pm 15,74 \%$ i 3 mjeseca $-711,35 \pm 15,84 \%$. Te su vrijednosti bile značajno različite od onih u ostalim dvjema skupinama. Za skupinu 2 (TAP) dobivena je mala je vrijednost za mikrotvrdoću - 72,72 $\pm 7,93 \%, 61,07 \pm 5,42 \%, 58,89 \pm$ $6,85 \%$, a za otpornost na lom vrijednosti su $752,85 \pm 16,76$ $\%, 743,00 \pm 16,54 \%, 724,55 \pm 16,28 \%$. Skupina 3 (Ledermix) imala je vrijednosti za mikrotvrdoću $110,56 \pm 28,25 \%$, $60,00 \pm 10,95 \%$ i $57,08 \pm 10,64 \%$, a za otpornost na lom $759,75 \pm 22,30 \%, 752,05 \pm 22,18 \%, 739,05 \pm 22,59 \%$. Vrijednosti vidi na slikama 1 i 2 .

Usporedba parova triju ispitanih skupina detaljno je prikazana na tablicama 1 i 2 . Značajna razlika uočena je između kalcijeva hidroksida, TAP-a i Ledermixa i kad je riječ o mikrotvrdoći radikularnog dentina i o otpornosti na lom. 


\section{Discussion}

Due to the complexity of the root canal system, biomechanical preparation by itself is incompetent in completely eradicating microorganisms. Recent research has revealed that the bacteria present in instrumented canals prior to completion of treatment can increase in number and reach their pretreatment count in about 2-4 days (35). Amongst the persistent bacteria within the root canal $E$. faecalis is the most resilient microorganism that causes persistent periapical lesions. In these cases, the use of intracanal medicaments is encouraged (36). The application time of intracanal medicaments varies depending upon its clinical use which may range from 1 to 4 weeks for decontamination of the root canal and even extend up to 11 weeks in cases of endodontic regeneration.

It has been affirmed that microhardness assessment gives an indirect substantiation of the mineral loss or gain in mineralized dental tissues as it is dependent upon the amount of calcified matrix per square millimeter (37). Arends and Bosch stated that microhardness testing is the most practical method of indirect quantitative analysis by accessing the amount of demineralization of dental hard tissues. Microhardness test provides an insight about the dentinal interaction with different medicaments (36).

Dentin may differ significantly between teeth and is associated with considerable number of variations. The tubular density of dentin has found to increase from cervical to apical areas of radicular dentin, which results in an inverse correlation amongst radicular dentinal microhardness and radicular tubular density. This may cause alterations in the results due to the variances in adjacent areas of the dentinal tissue (38). Hence, in the present study, the microhardness measurement was performed in the middle-third of the root structure for each sample.

Vickers microhardness testing was chosen since it is less affected by measurement errors. Despite small sized samples and surface conditions the specimens can be evaluated with good accuracy (36). There have been cumulative reports of demineralization, associated surface weakening and deterioration in the mechanical properties of radicular dentin which eventually led to microcracks and development of vertical root fracture following long term placement of intracanal medicaments (39). The assessment of the mechanical properties of radicular dentin can be done by fracture resistance studies as it relates to the amount of demineralization. Hence, the fracture resistance evaluation was chosen as the second parameter to be tested in this study. In this study, the force was generated at an angle of $0 \mathrm{o}$, which results in the development of a splitting stress over the tooth specimen. The stresses induced would be minimal because of less bending moments (40). In numerous clinical studies the immature permanent teeth treated by endodontic regeneration have shown an increase in the radicular dentinal wall thickness limited mainly to the middle and the apical third rather than the cervical region, thus weakening this region with an increased incidence of fracture; therefore, the cervical third of the root was chosen for fracture resistance test $(29,41)$.

\section{Rasprava}

Zbog kompleksnosti sustava korijenskog kanala, samo biomehanička preparacija nije dovoljna za potpunu eliminaciju mikroorganizama. Istraživanja su pokazala da broj bakterija u instrumentiranim kanalima prije završetka terapije može porasti do predterapijske razine za dva do četiri dana (35). Enterococcus faecalis ističe se kao najperzistentnija bakterija koja najčešć uzrokuje perzistirajuće periapikalne lezije. U tom se slučaju preporučuju intrakanalni lijekovi (36). Vrijeme primjene takvih uložaka razlikuje se ovisno o kliničkoj upotrebi, uglavnom u rasponu od jednoga do četiri tjedna za dekontaminaciju korijenskog kanala, pa čak do 11 tjedana u slučaju endodontske regeneracije.

Potvrđeno je da procjena mikrotvrdoće daje indirektnu informaciju o gubitku ili dobitku minerala u mineraliziranom dentalnom tkivu, zato što je ono ovisno o količini kalcificiranog matriksa po četvornom milimetru (37). Arends i Bosch ustanovili su da je ispitivanje mikrotvrdoće najpraktičnija indirektna kvantitativna metoda za procjenu količine demineralizacije tvrdih dentalnih tkiva. Ispitivanje mikrotvrdoće daje uvid u dentinsku interakciju s različitim lijekovima (36).

Dentin se prema sastavu može razlikovati od zuba do zuba, a i povezan je s nizom varijacija. Gustoća tubula dentina povećava se od cervikalnoga prema apikalnome dijelu radikularnog dentina, što za posljedicu ima obrnutu korelaciju između dentinske mikrotvrdoće i gustoće tubula. To može rezultirati razlikama u rezultatima zbog varijacija u okolnom dentinskom tkivu (38). U ovom istraživanju mjerenje mikrotvrdoće provedeno je u srednjem dijelu korijena svakog uzorka.

Odabrano je mjerenje mikrotvrdoće prema Vickersu zato što na njega manje utječu pogreške pri mjerenju te se unatoč sitnim uzorcima i stanju površine uzorke može dosta dobro precizno procijeniti (36). Kumulativni opisi demineralizacije, oštećenja površine i gubitak mehaničkih svojstava radikularnog dentina s vremenom mogu prouzročiti mikropukotine i okomite frakture korijena nakon dugotrajne primjene intrakanalnih lijekova (39). Procjena mehaničkih svojstava radikularnog dentina može se dobiti i istraživanjem otpornosti na lom zato što je povezana s demineralizacijom. Stoga je kao druga metoda odabrano ispitivanje otpornosti na lom. Sila je u ovom istraživanju djelovala pod kutom od nula stupnjeva, što rezultira stresom i pucanjem uzorka zuba. Izazvani stresovi minimalni su zbog toga što izostaje savijanje (40). U mnogobrojnim kliničkim istraživanjima nezrelih trajnih zuba liječenih endodontskom regeneracijom istaknuto je da se povećala debljina radikularnog dentina samo u srednjem i apikalnom dijelu korijena pa je cervikalni dio područje $s$ povećanom incidencijom lomova. Upravo zato je za ispitivanje otpornosti na lom odabrana cervikalna trećina korijena (29).

Budući da nikal-titanijevi instrumenti iz seta Protaper pokrivaju cijeli raspon liječenja s manjim brojem instrumenata, što uključuje veću fleksibilnost, nenadmašnu učinkovitost i povećanu sigurnost, oni se u preparaciji korijenskih kanala koriste češće nego čelični (54). Kako bi bili standardizirani, svaki je korijenski kanal prepariran Protaperom veličine F3, što odgovara veličini iglice br. 30 . 
As NiTi Protaper instruments are intended to cover the entire range of treatment with fewer files which integrate greater flexibility, unparalleled efficacy and enhanced safety. They have been used over stainless steel instruments in order to prepare the root canals. For the standardization of the root canal, each root was prepared up to Protaper size F3, which corresponds to ISO \#no. 30.

Manual agitation was done carefully in an attempt not to abrade the radicular dentin since it has been advocated that the persistence of endodontic intracanal medicament residues interact with the smear layer during instrumentation of the root canal $(42,43)$.

Hoshino et al. (10) recommended the usage of TAP (3Mix) - in a ratio 1:1:1. - Ciprofloxacin 200mg, Metronidazole 500mg, Minocycline 100mg. Ciprofloxacin and Minocycline have found to have minimal inhibitory concentration of 5 and $20 \mu \mathrm{g}$ against $E$. feacalis and Metronidazole was stated to have no inhibitory effects (57). However, as a combination $(100 \mu \mathrm{g}$ each $/ \mathrm{ml})$ they have proven to inhibit entirely the growth of every strain (58). In regenerative endodontics, increased concentrations of TAP cause cytotoxic effects on the stem cells of dental pulp and apical papilla. Therefore, decreased concentration in a range of $0.1 \mathrm{mg} / \mathrm{mL}$ to $2 \mathrm{mg} /$ $\mathrm{mL}$ has been recommended.

The lowest scores for microhardness and fracture resistance were shown by Group I Calcium hydroxide at 1 week, 1 month and 3 months, respectively. The present result could be explained by the alkaline $\mathrm{pH}$ of calcium hydroxide and its low molecular weight which denatures the collagenous matrix (44). The results of the present study are consistent with a recently performed study by Yassen et al. which showed that $\mathrm{Ca}(\mathrm{OH})_{2}$ produced substantial collagen degradation of superficially present root canal dentine after a short duration of 1 -week (45). It is well understood that the collagen constituent is accountable for the toughness of the mineralized hard tissues, hence any defect produced compromises the mechanical properties making it more susceptible to fracture, which has been seen in this study after 3 months. Long term application of $\mathrm{Ca}(\mathrm{OH})$ also enhances crack propagation (44). Increased susceptibility to fracture was seen in this study's 3 -month fracture resistance data. Group II (Triple Antibiotic Paste) showed the scores for microhardness of $(72.72 \pm 7.93$ $\%),(61.07 \pm 5.42 \%),(58.89 \pm 6.85 \%)$, and the fracture resistance scores were $(752.85 \pm 16.76 \%),(743.00 \pm 16.54 \%)$, $(724.55 \pm 16.28 \%)$ at 1 week, 1 month and 3 months respectively. This may be credited to various acids commonly mixed with antibiotics to preserve their chemical steadiness and to regulate their tonicity. The results of the present study totally reject the null hypothesis.

Minocycline causes chelation of calcium, which in turn contributes to demineralization $(44,45)$. Studies show that increased concentration of TAP is directly proportional to the surface roughness (46). This also causes reduction in the inorganic content and loss of dentin, which decreases the wettability of dentin surfaces (47). The results obtained in the present research are in line with studies conducted by Yassen et el (2013) and Kinney et al. (2003) that demonstrated that $1 \mathrm{~g} / \mathrm{mL}$ TAP caused severe reduction in microhardness and
Manualna agitacija provedena je nježno kako se ne bi dogodila abrazija radikularnog dentina, zato što je poznato da zadržavanje intrakanalnog lijeka utječe na zaostatni sloj tijekom instrumentacije (43). Hoshino i suradnici preporučili su korištenje TAP-a (3Mix) u omjeru 1:1:1 (ciprofloksacin $200 \mathrm{mg}$, metronidazol $500 \mathrm{mg}$, minociklin $100 \mathrm{mg}$ ). Ciprofloksacin i minociklin imaju minimalnu inhibitornu koncentraciju za $E$. faecalis od 5 do $20 \mu \mathrm{g}$, a metronidazol nema nikakvo inhibitorno djelovanje na tu bakteriju (57). No pokazalo se da kombinacija $(100 \mu \mathrm{g}$ svakog antibiotika/mL) inhibira rast svih vrsta mikroorganizama (58). U regenerativnoj endodonciji povećana koncentracija TAP-a potiče citotoksične učinke na matičnim stanicama pulpe $\mathrm{i}$ apikalne papile. Zato se preporučuje smanjena koncentracija u rasponu od 0,1 $\mathrm{mg} / \mathrm{mL}$ do $0,2 \mathrm{mg} / \mathrm{mL}$.

Najniže vrijednosti mikrotvrdoće i otpornosti na lom zabilježene su u skupini 1 (kalcijev hidroksid) nakon jednoga tjedna, mjesec dana i tri mjeseca. Ti rezultati možda su prouzročeni alkalnim pH kalcijeva hidroksida i njegovom niskom molekularnom masom koja denaturira kolageni matriks (44). Rezultati našeg istraživanja u skladu su s nedavno objavljenim radom Yassena i suradnika u kojem se ističe da $\mathrm{Ca}(\mathrm{OH})_{2}$ izaziva značajnu degradaciju kolagena površinskog dentina u korijenskom kanalu nakon samo tjedan dana (45). Jasno je da je kolagen odgovoran za čvrstoću mineraliziranoga tkiva pa svaki njegov defekt kompromitira mehanička svojstva tkiva koje postaje osjetljivo na frakture, baš kao što smo i mi potvrdili nakon tri mjeseca. Dugotrajna primjena kalcijeva hidroksida potiče širenje pukotina (44). Povećana osjetljivost na lom uočena je u našem istraživanju na uzorcima nakon tri mjeseca. U skupini 2 (TAP) zabilježena je vrijednosti za mikrotvrdoću $72,72 \pm 7,93 \%, 61,07 \pm 5,42 \%$ i $58,89 \pm 6,85$ $\%$, a za otpornost na lom 752,85 $\pm 16,76 \%, 743,00 \pm 16,54$ $\%$ i $724,5 \pm 16,28 \%$ nakon tjedan dana, mjesec dana i tri mjeseca. To se može pripisati različitim kiselinama koje se dodaju antibioticima da bi se sačuvala njihova kemijska aktivnost te kontrolirao tonicitet. Rezultati dobiveni u ovom istraživanju u cijelosti odbacuju nultu hipotezu.

Minociklin uzrokuje kelaciju kalcija, što pogoduje demineralizaciji (44). Istraživanja pokazuju da je povećana koncentracija TAP-a izravno proporcionalna hrapavosti površine (46). To također smanjuje anorganski sadržaj i gubitak dentina, što smanjuje mogućnost njegova vlaženja (47). Rezultati našeg istraživanja u skladu su s onima koje su objavili Yassen i suradnici te Kinney i suradnici koji su naveli da $1 \mathrm{~g} / \mathrm{mL}$ TAP-a značajno reducira mikrotvrdoću i otpornost na lom radikularnog dentina nakon tjedan i mjesec dana. TAP povećava udio organskog sadržaja $(29,48)$. Razlog za promjene u kemijskim svojstvima radikularnog dentina nakon upotrebe TAP-a jest kiselost $(\mathrm{pH}=2,9)$ pa zbog toga nastaje površinska demineralizacija (29). TAP manje negativno djeluje na kemijsku strukturu radikularnog dentina od $\mathrm{CH}$-a, što smo i mi potvrdili u ovom istraživanju. Vrijeme je važan čimbenik, jer je dulja izloženost izravno proporcionalna s demineralizacijom (26). Rezultati koje su objavili Madhusudhana i suradnici u skladu su s našim istraživanjem (40).

$\mathrm{Na}$ uzorcima izloženima Ledermixu zabilježena je manja redukcija mikrotvrdoće i otpornosti na lom radikularnog de- 
fracture resistance of the radicular dentin at time intervals of 1 week and 1 month. TAP increases the organic content $(29,48)$. The reason attributed to the change in the chemical properties of radicular dentin following the use of TAP is due to its acidic ability $(\mathrm{pH}=2.9)$ and associated surface demineralization (29). TAP has a less negative effect on the chemical structure of radicular dentin compared to $\mathrm{CH}$ which was also found in the present study. Time period being an important factor, the increased exposure time is directly proportional to demineralization (26). The results obtained by Madhusudhana K et al. are consistent with the results of the present study (40).

The samples exposed to Ledermix intracanal medicament showed less reduction in the radicular dentin microhardness and fracture resistance. This could be attributed to its lower $\mathrm{pH}(8.76)$ compared to the $\mathrm{Ca}(\mathrm{OH})_{2}$ intracanal medicament (65). It has been proposed that a higher alkaline $\mathrm{pH}$ may cause denaturation of the organic matrix or result in the collapse of the dentine inorganic matrix. Studies have found that the denaturing of organic matrix is promoted by high $\mathrm{pH}$ (49). There is encapsulation of the organic matrix by the inorganic hydroxyapatite, and the penetration of the intracanal medicament requires greater time (e.g., 4 weeks in some studies), thus making the dentinal structure more brittle with an increased susceptibility to fracture.

Further in vivo studies are needed in order to apply the results obtained from the present study in clinical setting. There is insufficient evidence to current protocols followed in regenerative endodontics. This has been proposed based upon research and previous case reports. The area of regenerative endodontics is still in its budding stage where we need evidence-based data to determine the best treatment time, the best medicament(s), and the best concentration without compromising the physical properties of the tooth.

\section{Conclusions}

Within the parameters of this in vitro study, the null hypothesis has been rejected and the following conclusions can be drawn: The results of the present study suggest avoiding long term use of intracanal medicaments which are generally used in regenerative endodontics to obtain a sterile environment to promote growth. The three-month application of $\mathrm{Ca}(\mathrm{OH})_{2}$ TAP and Ledermix intracanal medicaments significantly decreased the fracture resistance and microhardness of radicular dentin compared to the 1-week application. A prolonged exposure of intracanal medicaments has adverse effects on chemical and mechanical properties of root canal dentin.

Limitations:-Further research is needed in order to optimize the time of application in various long term endodontic procedures and to investigate the demineralization effect of TAP and Ledermix.

\section{Informed Consent Statement}

Informed consent was obtained from all subjects involved in the study nina. To bi se moglo pripisati njegovu nižem $\mathrm{pH}(8,76)$ u usporedbi s kalcijevim hidroksidom. Sumnjalo se da viši, alkalni pH može potaknuti denaturaciju organskoga matriksa ili kolaps anorganskoga matriksa dentina. Istraživanja su pokazala da denaturaciju organskoga matriksa uzrokuje visoki $\mathrm{pH}$ (49). Događa se enkapsulacija organskoga matriksa anorganskim hidroksiapatitom, a za prodor lijeka u kanal treba više vremena (npr. 4 tjedna u nekim istraživanjima), nakon čega dentinska struktura postaje krhkija i sklona pucanju.

Buduća istraživanja in vivo trebala bi ispitivati rezultate našeg istraživanja u kliničkom okružju. Nema dovoljno dokaza za trenutačne protokole koji se primjenjuju u regenerativnoj endodonciji, a oni su predloženi na temelju istraživanja i ranijih uspješnih slučajeva. Područje regenerativne endodoncije još uvijek je u razvojnoj fazi pa su nam potrebni podatci potkrijepljeni dokazima kako bismo odredili najbolju terapiju, najučinkovitije lijekove i njihovu najvišu moguću koncentraciju, bez kompromitiranja fizičkih svojstava zuba.

\section{Zaključak}

Unutar ograničenja ovoga istraživanja in vivo opovrgnuta je nulta hipoteza te je bilo moguće zaključiti sljedeće: rezultati ovog istraživanja pokazuju da treba izbjegavati dugotrajnu upotrebu intrakanalnih medikamenata uopće u regenerativnoj endodonciji u svrhu postizanja sterilnog okoliša u kojemu može doći do rasta. Tromjesečna primjena kalcijeva hidroksida, TAP-a i Ledermixa u kanalu značajno je smanjila otpornost na lom i mikrotvrdoću radikularnog dentina u usporedbi s primjenom od tjedan dana. Produljena primjena intrakanalnih lijekova nepovoljno utječe na mehanička svojstva dentina korijenskog kanala.

Ograničenja: potrebna su daljnja istraživanja optimizacije vremena primjene u različitim dugotrajnim endodontskim postupcima te je potrebno ispitati demineralizacijski učinak TAP-a i Ledermixa.

\section{Informirani pristanak}

Informirani pristanak dobiven je od svih ispitanika. 


\section{Conflicts of Interest}

The authors declare no conflict of interest.

\section{Funding}

This research received no external funding.

Author's contribution: A. D. A. - Concepts, design, definition of intellectual content, literature search, clinical studies, experimental studies, data acquisition, data analysis, statistical analysis, manuscript preparation, manuscript editing and manuscript review; N. S. D. Concepts, design, definition of intellectual content, clinical studies, experimental studies, data analysis, manuscript preparation, manuscript editing and manuscript review; P. K. D., A. Z. and L. T. - Concepts, design, experimental studies, manuscript editing and manuscript review; A. C. P., S. P. - Concepts, experimental studies; S. M. H. - Concepts, manuscript editing and manuscript review.

\section{Sukob interesa}

Autori nisu bili u sukobu interesa.

\section{Financiranje}

Ovo istraživanje nije financirao nitko izvan Sveučilišta.

Doprinos autora: A. D. A. - koncepti, dizajn, definicija intelektualnog sadržaja, pretraživanje literature, kliničke studije, eksperimentalne studije, prikupljanje podataka, analiza podataka, statistička analiza, priprema, uređivanje i pregled rukopisa; N. S. D. - koncepti, dizajn, definicija intelektualnog sadržaja, kliničke studije, eksperimentalne studije, analiza podataka, priprema, uređivanje i pregled rukopisa; P. K. D., A. Z. i L. T. - koncepti, dizajn, eksperimentalne studije, uređivanje i pregled rukopisa; A. C. P., S. P. - koncepti, eksperimentalne studije; S. M. H. - pojmovi, uređivanje i pregled rukopisa.

\section{Sažetak}

Cilj rada: Željelo se procijeniti kako dugotrajna upotreba triju intrakanalnh lijekova utječe na mikrotvrdoću i otpornost na lom radikularnog dentina. Materijal i metode: Kemomehanička preparacija obavljena Protaperovim rotirajućim instrumentima do F3. Zubi su zatim stavljeni u inkubator i čuvani na temperaturi od $37^{\circ} \mathrm{C} \mathrm{u} 100$ posto vlažnom okružju te su slučajnim odabirom podijeljeni u tri skupine: trostruka antibiotička pasta (TAP), pasta od kalcijeva hidroksida (Apexcal), Ledermix. Nakon primjene lijekova svi su ulazni otvori zabrtvljeni $4 \mathrm{~mm}$ debelim slojem Cavita. Uzorci su zatim uskladišteni tjedan dana, mjesec dana i tri mjeseca. Od svakog uzorka uzeta su po dva dentinska cilindra debljine 3 i $5 \mathrm{~mm}$. Za otpornost na lom korištena je cervikalna trećina, a za procjenu mikrotvrdoće srednja trećina. Mikrotvrdoća je ispitana testerom Knoop Microhardness, a otpornost na lom univerzalnim ispitnim uređajem. Rezultati: Kalcijev hidroksid najsnažnije je negativno djelovao na fizička svojstva radikularnog dentina u usporedbi s TAP-om ( $p=0,0100$ nakon mjesec dana) i Ledermixom $(p=0,0001$ nakon mjesec dana). Kako se povećavalo razdoblje djelovanja, tako su se pogoršavala fizička obilježja radikularnog dentina. Zaključak: Dugotrajno korištenje kalcijeva hidroksida, TAP-a i Ledermixa ( $p=0,0001$ nakon 3 mjeseca) znatno utječe na mikrotvrdoću i otpornost na lom radikularnog dentina.
Zaprimljen: 8. svibnja 2021.

Prihvaćen: 1. kolovoza 2021.

Adresa za dopisivanje

Alessio Zanza

Sveučilište Sapienza

Zavod za oralnu i maksilofacijalnu

kirurgiju

$\operatorname{Rim} 00185$

Italija

ale.zanza@gmail.com

MeSH pojmovi: materijali za punjenje korijenskog kanala; dentin; testovi tvrdoće; čvrstoća na savijanje Ključne riječi: Ledermix, trostruka antibiotička pasta, mikrotvrdoća, otpornost na lom, kalcijev hidroksid

\section{References}

1. Vertucci FJ. Root canal morphology and its relationship to endodontic procedures. Endod Top. 2005;10:3-29.

2. Sato I, Ando-Kurihara N, Kota K, Iwaku M, Hoshino E. Sterilization of infected root-canal dentine by topical application of a mixture of ciprofloxacin, metronidazole and minocycline in situ. Int Endod J. 1996 Mar;29(2):118-24.

3. Hulsmann M, Peters OA, Dummer PMH. Mechanical preparation of root canals: shaping goals, techniques and means. Endo Top. 2005;10:30-76.

4. Narayanan LL, Vaishnavi C. Endodontic microbiology. J Conserv Dent. 2010 Oct;13(4):233-9.

5. Sathorn C, Parashos P, Messer HH. How useful is root canal culturing in predicting treatment outcome? J Endod. 2007 Mar;33(3):220-5.

6. Schoop U, Kluger W, Dervisbegovic S, Goharkhay K, Wernisch J, Georgopoulos A, et al. Innovative wavelengths in endodontic treatment. Lasers Surg Med. 2006 Jul;38(6):624-30.

7. Galler KM. Clinical procedures for revitalization: current knowledge and considerations. Int Endod J. 2016 Oct;49(10):926-36.

8. Farhad A, Mohammadi Z. Calcium hydroxide: a review. Int Dent J. 2005 Oct;55(5):293-301.

9. Muruganandhan J, Sujatha G, Poorni S, Srinivasan MR, Boreak $\mathrm{N}$, Al-Kahtani A, et al. Comparison of four dental pulp-capping agents by cone-beam computed tomography and histological techniques - a split-mouth design ex vivo study. Applied Sciences (Switzerland). 2021;11(7).

10. Karataş $\mathrm{E}$. The time dependent effect of various irrigation systems on the reduction of $\mathrm{E}$. faecalis in experimentally infected root canals. Turkish Endod J. 2016;1:23-29.

11. Schouten MA, Hoogkamp-Korstanje JA, Meis JF, Voss A. European VRE Study Group Prevalence of vancomycin-resistant enterococci in Europe. Eur J Clin Microbiol Infect Dis. 2000 Nov;19(11):816-22.
12. Desai S, Chandler N. Calcium hydroxide-based root canal sealers: a review. I Endod. 2009 Apr:35(4):475-80.

13. Mohammad Z, Dummer PMH. Properties and applications of calcium hydroxide in endodontics and dental traumatology. Int Endod J. 2011 Aug;44(8):697-730.

14. Kawamoto R, Kurokawa H, Takubo C, Shimamura Y Yoshida T, Miyazaki $M$. Change in elastic modulus of bovine dentine with exposure to a calcium hydroxide paste. J Dent. 2008 Nov;36(11):95964.

15. Shaik J, Garlapati R, Nagesh B, Sujana V, Jayaprakash T, Naidu S. Comparative evaluation of antimicrobial efficacy of triple antibiotic paste and calcium hydroxide using chitosan as carrier against Candida albicans and Enterococcus faecalis: An in vitro study. J Conserv Dent. 2014 Jul;17(4):335-9.

16. Davey P, Wilcox MH, Irving W, Thwaites G. Antimicrobial Chemo therapy; Oxford University Press; 2015: ISBN 9780199689774.

17. Friedlander LT, Cullinan MP, Love RM. Dental stem cells and their potential role in apexogenesis and apexification. Int Endod J. 2009 Nov;42(11):955-62.

18. Rafter M. Apexification: a review. Dent Traumatol. 2005 Feb;21(1):1-8.

19. Moleri AB, Moreira LC. Complexo dentino-pulpar. In: Lopes HP . editor. Siqueira Júnior, JF Endodontia: biologia e técnica. 3 rd ed. Rio de Janeiro: 2011.

20. Diogenes A, Ruparel NB, Shiloah Y, Hargreaves KM. Regenerative endodontics: A way forward. J Am Dent Assoc. 2016 May;147(5):372-80.

21. Fouad AF. The microbial challenge to pulp regeneration. Adv Dent Res. 2011 Jul;23(3):285-9.

22. Prather BT, Ehrlich Y, Spolnik K, Platt JA, Yassen GH. Effects of two combinations of triple antibiotic paste used in endodontic regeneration on root microhardness and chemical structure of radicular dentine. J Oral Sci. 2014 Dec;56(4):245-51. 
23. Lin LM, Shimizu E, Gibbs JL, Loghin S, Ricucci D. Histologic and histobacteriologic observations of failed revascularization/revitalization therapy: a case report. J Endod. 2014 Feb;40(2):291-5.

24. Fouad A, Nosrat A. Pulp regeneration in previously infected root canal space. Endod Top. 2013; 28.

25. AEE clinical considerations for a regenerative procedure. Am As soc endodontist. 2015.

26. Parhizkar A, Nojehdehian H, Asgar S. Triple antibiotic paste: momentous roles and applications in endodontics: a review. Restor Dent Endod. 2018 Jun 20;43(3):e28.

27. Kim H, Kim Y, Shin SJ, Park JW, Jung IY. Tooth discoloration of immature permanent incisor associated with triple antibiotic therapy: a case report. J Endod. 2010 Jun;36(6):1086-91.

28. Petrino JA, Boda KK Shambarger S, Bowle WR, McClanahan SB. Challenges in regenerative endodontics: a case series. J Endod. 2010 Mar;36(3):536-41.

29. Yassen GH, Eckert J, Platt JA. Effect of intracanal medicaments used in endodontic regeneration procedures on microhardness and chemical structure of dentin. Restor Dent Endod. 2015 May;40(2):104-12.

30. Cowan A. Treatment of exposed vital pulps with a corticosteroid antibiotic agent. Br Dent J. 1966 Jun 7;120(11):521-32.

31. Mohammad Z. Systemic and local applications of steroids in endodontics: an update review. Int Dent J. 2009 Oct;59(5):297-304.

32. Pierce A, Heithersay G, Lindskog S. Evidence for direct inhibition of dentinoclasts by a corticosteroid/antibiotic endodontic paste. Endod Dent Traumatol. 1988 Feb;4(1):44-5.

33. Won KS, Sae-Lim V. The effect of intracanal Ledermix on root resorption of delayed-replanted monkey teeth. Dent Traumatol. 2002 Dec;18(6):309-15.

34. Chen H, Teixeira FB, Ritte A, Levin L Trope M. The effect of intraca nal anti-inflammatory medicaments on external root resorption of replanted dog teeth after extended extra-oral dry time. Dent Traumatol. 2008 Feb;24(1):74-8.

35. Zehnder M. Root canal irrigants. J Endod. 2006 May;32(5):389 98.

36. Prabhakar A, Taur S Hadakar S, Sugandhan S. Comparison of Antibacterial Efficacy of Calcium Hydroxide Paste, $2 \%$ Chlorhexidine Gel and Turmeric Extract as an Intracanal Medicament and their Effect on Microhardness of Root Dentin: An in vitro Study. Int J Clin Pediatr Dent. 2013 Sep;6(3):171-7.
37. Vijayaraghav R, Mathian VM, Sundaram M, Karunakaran R, Vinodh S. J Pharm Bioallied Sci. 2012 Aug;4(Suppl 2):S230-3.

38. Oktay EA, Ersahan S, Gokyay S. Pak J Med Sci. Mar-Apr 2018;34(2):310-315

39. Komabayashi T, Nonomura G, Watanabe LG, Marshall GW, Marshall SJ. J Dent. 2008 Nov;36(11):953-8.

40. Patil U, Yeli M, Tapashetti S, Naik B, Tilakchand M. Effect of varying durations of intracanal medicament application used in regenerative endodontic treatment on the push-out bond strength of a novel cement: NeoMTA Plus. J Conserv Dent. Jan-Feb 2019;22(1):48-53.

41. Bhat SS, Hegde SK, Rao A, Shaji Mohammed AK. Evaluation of re sistance of teeth subjected to fracture after endodontic treatment using different root canal sealers: an in vitro study. J Indian Soc Pedod Prev Dent. Oct-Dec 2012;30(4):305-9.

42. Zand V, Lotfi M, Soroush M,Abdollahi A, Sadeghi M, Mojadadi A Antibacterial Efficacy of Different Concentrations of Sodium Hypochlorite Gel and Solution on Enterococcus faecalis Biofilm. Iran Endod J. Fall 2016;11(4):315-319.

43. Nagas E, Cehreli ZC, Uyanik MO, Vallittu PK, Lassila LVJ. Effect of several intracanal medicaments on the push-out bond strength of ProRoot MTA and Biodentine. Int Endod J. 2016 Feb;49(2):184-8.

44. Bansal R, Jain A. Overview on the current antibiotic containing agents used in endodontics. N Am J Med Sci. 2014 Aug;6(8):3518

45. Kristich CI, Rice B, Arias CA. Enterococcal Infection-Treatment and Antibiotic Resistance. Enterococci From Commensals to Lead. Causes Drug Resist. Infect. 2014.

46. Yassen, G. The effect of endodontic regeneration medicaments on mechanical properties of radicular dentin. 2013

47. Yassen GH, Platt JA. The effect of nonsetting calcium hydroxide on root fracture and mechanical properties of radicular dentine: a systematic review. Int Endod J. 2013 Feb;46(2):112-8.

48. Minabe M, Takeuchi K, Kumada H, Umemoto T. The effect of root conditioning with minocycline $\mathrm{HCl}$ in removing endotoxin from the roots of periodontally-involved teeth. J Periodontol. 1994 May;65(5):387-92.

49. Abou Neel EA, Aljabo A, Strange A, Ibrahim S, Coathup M, Young, et al. Int J Nanomedicine. 2016 Sep 19;11:4743-4763. 